\title{
USE OF ENZYME ALPHA AMYLASE TO INCREASE BIOGAS YIELD FROM LUCERNE PELLETS AND BIRCH LEAVES PELLETS
}

Vilis Dubrovskis, Imants Plume, Indulis Straume

Latvia University of Life Sciences and Technologies, Latvia

vilisd@inbox.lv, imants.plume@1lu.lv, indulis.straume@1lu.lv

\begin{abstract}
More and more biogas plants use pellets from various residues as a raw material. Their advantage is not only cheaper transport over longer distances, but also they absorb moisture well and do not form a floating layer in the fermentation reservoir. Hydraulic retention time of pellets, containing such raw materials as birch leaves, in the anaerobic digester is relatively long and requires large volumes of bioreactors. Variety of additives can be used to improve the anaerobic digestion process. This article shows the results of the study where the enzyme Alpha amylase is used for the digestion process improvement. Lucerne pellets and birch leaves pellets were digested in the laboratory 0.751 bioreactors at the temperature $38^{\circ} \mathrm{C}$ using a single filling cycle. Two biorectors contained inoculums and were processed for control purposes only. Other 14 biorectors contained inoculums with added pellets and with or without enzymes additive. Average specific biogas or methane yield in anaerobic fermentation of lucerne or birch leaves pellets was $0.401 \mathrm{l} \cdot \mathrm{g}^{-1} \mathrm{DOM}^{\text {or }} 0.263 \mathrm{l} \cdot \mathrm{g}^{-1}$ DOM respectively. Average specific biogas or methane yield in anaerobic fermentation of birch leaves pellets was $0.245 \mathrm{l} \cdot \mathrm{g}_{\text {DOM }}^{-1}$ or $0.214 \mathrm{l} \cdot \mathrm{g}^{-1}$ DOM respectively. Addition of enzymes $(0.5 \mathrm{ml}$ per bioreactor $)$ in bioreactors with lucerne pellets and birch leaves pellets increases the average methane yield by $19.95 \%$ or $22.9 \%$ respectively.
\end{abstract}

Keywords: anaerobic digestion, methane, enzymes, lucerne pellets, birch leaves pellets.

\section{Introduction}

"A key strategy allied with today is to develop an alternative energy source instead of fossil fuels in order to compensate the present energy need, in addition to reduce environmental concerns owed by pollution and global warming. Energy generation in feasible manner without possessing environmental crash is a difficult task where alternative concepts were requisite to ensure sustainable development with accessible technologies" [1]. "Further advances triggered renewed attention in biogas production technology, while it has great impacts on diminishing major economic issues raised in the world. In the light of these strategies, the present review intended to critically evaluate the recent technological advances and promising prospects coupled with various aspects of biogas production, such as sustainable feedstock utilization, microbial and enzyme dynamics, parameter optimization and process segregation, for enhancing this technology in outlook. Appropriate selection, co-digestion and biotransformation offer a great challenge that craft substrate to become more energy efficient, besides to trim down the constraints behind the principle of biomass utilization. A basic framework for process stimulation with microorganisms and enzyme preparations explored that further experimental trials by means of identification of efficient microbes and standardization of enzyme dynamics would augment the feasibility of energy flow during anaerobic digestion"[1]. Review of the different constraints behind anaerobic technology and different aspects for enhancement of biogas production through addition of enzymes and microorganisms is provided in the above mentioned paper.

Researchers have tried different techniques to enhance gas production.

"Organic waste is an important resource for biogas production. The biodegradability of manure is however limited because of the recalcitrant nature of the biofibers it contains. To increase the biogas potential of the biofibers in digested manure we investigated physical treatment (milling), chemical treatment $(\mathrm{CaO})$, biological treatment (enzymatic and partial aerobic microbial conversion), steam treatment with catalyst $(\mathrm{H}(3) \mathrm{PO}(4)$ or $\mathrm{NaOH})$ and combination of biological and steam treatments (biofibers steam-treated with catalyst were treated with laccase enzyme)" [2]. Researchers succeeded using all biomass pre-treatment methods described above. "We obtained the highest methane yield increase through the chemical treatment that resulted in $66 \%$ higher methane production compared to untreated biofibers. The combination of steam treatment with $\mathrm{NaOH}$ and subsequent enzymatic treatment increased the methane yield by $34 \%$. To choose the optimal treatment, the energy requirements relative to the energy gain as extra biogas production have to be taken into account, as well as the costs of chemicals or enzymes" [2].

"The different enzymes or enzyme mixtures can be used for enhancement of anaerobic treatment of organic biomass. Polish researchers investigated a multi-enzymatic biopreparation of 
Trichodermaatroviride G79/11 origin for AD process enhancement. "The enzyme mixturewas characterized by the following activities: xylanase, $\beta$-glucosidase, carboxymethylcellulase, polygalactouronase, pectinesterase, amylase, lactase, and protease. A method for an efficient conditioning process of organic waste (fruit processing waste, dairy sewage sludge, corn silage, and grain broth) for biogas yield enhancement using the enzyme mixture was proposed. The enzyme mixture increased the efficacy of biogas production by $30 \%$ when the lyophilizate $0.5 \mathrm{mg} \cdot \mathrm{g}^{-1} \mathrm{~d} . \mathrm{m}$.) was applied prior to fermentation. A method for conducting the enzymatic conditioning process of organic waste using the enzyme mixture as pretreatment was proposed. This was part of the optimization of the methane fermentation process to increase the biogas yield. Consequently, after application of the biopreparation, the efficiency of anaerobic digestion of organic waste was improved"[3].

Special attention from scientists around the world is directed to the improvement of anaerobic fermentation quality andeconomic indicators of biogas production from lignocellulosic materials, such as straw, wood residues, tree leaves. "There have been studies on the improvement of biogas production from lignocellulolytic materials, one of the largest and renewable sources of energy on the earth, after pre-treatment with cellulases and cellulase-producing microorganisms"[4].

Reducing the cost of enzymes is also the focus of researchers. "Enzymes that break down biomass are already present in anaerobic digesters, as they are produced by the microorganisms of anaerobic digestion. To enhance this breakdown a mixture of enzymes can be added, and may include cellulose-, hemicellulose-, pectin- and starch-degrading enzymes" [5].

The addition of enzymes into substrates for anaerobic digestion has been evaluated in many different studies [6-8].

"An experimental studywas conducted that promoted the efficiency of anaerobic digestion by hydrolyzing pig manure in advance with amylase before loading it into the digester."[7]. "The results showed that the removal percentage of TS and VS, the biogas production potentials and rates have been improved through the amylase pre-treatment. Especially through the amylase and $\gamma$-amylase pretreatment together, the removal percentage of TS and VS, as compared with the control group, was increased by $10.84 \%$ and $11.11 \%$ respectively, the biogas production potential increased by $13.10 \%$, and the specific biogas production rate increased by $9.30 \%$ [7]".

"A modified $2 \times 2$ factorial experiment with 19 steers was used to study $\mathrm{CH}_{4}, \mathrm{CO}_{2}$ and heat production, and $\mathrm{O}_{2}$ utilization and the energy digestibility of pelleted and chopped first- and secondcut alfalfa at maintenance and 1.6 times maintenance in steers. Methane production, dry matter digestibility and urinary energy loss were reduced $(P<0.05)$, when first-cut alfalfa was pelleted but pelleting had no influence on these parameters with second-cut alfalfa. Methane and $\mathrm{CO}_{2}$ production and $\mathrm{O}_{2}$ utilization increased sharply after feeding. There were interactions between the type of feed (chopped vs. pelleted) and cut of alfalfa in $\mathrm{CH}_{4}\left(1 \cdot \mathrm{kg}^{-1}\right.$ feed $\left.\mathrm{DM}\right)$, and $\mathrm{CO}_{2}$ production and $\mathrm{O}_{2}$ utilization. Energy digestibility and $\mathrm{CH} 4$ losses were similar at maintenance and 1.6 times maintenance level of feeding. Although methane production was lower in cattle fed pellets in three out of four comparisons of pelleted and chopped hay diets, the decline in energy loss as $\mathrm{CH} 4$ due to pelleting was not sufficient to justify the extra energy expended to pellet diets from an environmental or economic point of view" [8].

There is some evidence to suggest that enzymes used for pretreatment of brewer's spent grains resulted in qualitative and quantitative effects on biogas production. "The result shows that enzyme application promotes the hydrolysis of ligno-cellulose, indicated by higher enzymatic solubility and fatty acid concentration in a hydrolytic bioreactor. Moreover, biogas production is also increased. The quality of the gases produced is also enhanced. Since anaerobic digestion can be operated in a stable performance, it can also be concluded that SSF enzyme is compatible with anaerobic digestion" [9].

Batch anaerobic digestion studies in the laboratory bioreactors with volume $0.72 \mathrm{ml}$ have indicated that the addition of enzymes to corn silage and grain residues leads to slight increase of biogas and methane production. "Addition of enzyme mixture $(0.5 \mathrm{~g})$ in bioreactors with corn silage or grain processing residues increases the average methane yield by $7.76 \%$ or $4.48 \%$ respectively. Addition of catalyst Metaferm $(1 \mathrm{ml})$ into bioreactors with corn silage or grain processing residues increases the average methane yield by $1.79 \%$ or $6.72 \%$ respectively [10]. 
Researchers have investigated improvement of biogas production by adding intoAD substrate some bacteria and fungi strains. "Cellulolytic strains of bacteria like actinomycetes and mixed consortia have been found to improve biogas production in the range of 8.4-44\% from cattle dung" [11].

Thermophilic $\left(55^{\circ} \mathrm{C}\right)$ methanation of source-sorted household solid waste (HSW) and effects of additions of xylanase, lipase, protease and a mixture of these were studied in batch and in continuous experiments. "The results showed that the HSW was readily digestible, up to 400$590 \mathrm{mlCH}_{4} \cdot \mathrm{g}^{-1}$ volatile solids (VS) were produced. Only with protease added, at a concentration of 1.1 Anson protease units $\cdot \mathrm{kg}_{\mathrm{vs}}{ }^{-1}$, a higher specific methanogenic activity found was with active enzymes compared to inactive (autoclaved) enzymes or without enzyme addition. The methane yield by conversion of the HSW in the batch assays and in the reactor studies was not increased by enzyme additions (enzyme mixture)" [12].

The aim of this study is evaluation of the biogas and methane production potential from lucerne pellets and birch leaves pellets. We did not find any research on biogas extraction from birch leaves pellets in Latvia. The purpose of this research is evaluation of the effect of addition of enzyme Alpha amylase in the anaerobic digestion (AD) process of lucerne pellets and birch leaves pellets.

\section{Materials and methods}

Contents of organic matter were analysed in the samples of the raw materials (lucerne pellets and birch leaves pellets) before fermentation. Normally, lucerne is a good feed with high protein content (15-17\%) and with fiber content 26-32\%. Birch leaves also have highfiber content. Data on the content of organic matter were used for optimizing of the organic load of substrate.

Enzyme Alpha-amylase (code EC 3.2.1.1) is a protein enzyme that hydrolyses polysaccharides, such as starch and glycogen, yielding glucose and maltose. It is the major form of amylase found in humans and other mammals. It is also present in seeds containing starch as a food reserve and is secreted by many fungi.

The widely used methods were implemented for the experimental investigation of lucerne pellets and birch leaves pellets in the anaerobic fermentation process [10;13;14]. Laboratory experimental research was provided in 16 bioreactors with the volume of 0.75 litres each, filled with $500.00 \mathrm{ml}$ inoculums (finally fermented cow manure). Control bioreactors (2 pcs.) were processed with pure inoculums only to obtain biogas and methane volumes from inoculums to calculate true biogas or methane volumes obtainable from added biomass, according to the experimental plan, see Table 1.

Bioreactors R2-R4 were filled with a mixture containing $500 \mathrm{~g}$ and $10 \mathrm{~g}$ lucerne pellets. Bioreactors R5-R8 were filled with mixture of $500 \mathrm{~g}$ inoculums, $10 \mathrm{~g}$ lucerne pellets and $0.5 \mathrm{ml}$ enzyme alpha amylase. Bioreactors R9-R11 were filled with 500g inoculums and $10 \mathrm{~g}$ birch leaves pellets. Bioreactors R12-R15 were filled with $500 \mathrm{~g}$ inoculums, $10 \mathrm{~g}$ lucerne pellets, and $0.5 \mathrm{ml}$ enzyme Alpha amylase.

For investigation of total solid samples of lucerne pellets and birch leaves pellets they were weighted (accuracy $\pm 0.001 \mathrm{~g}$ ), dried in the thermostat at $105^{\circ} \mathrm{C}$ and placed for investigation of dry organic matter (DOM) in the oven (brand "Naberherm") at $550{ }^{\circ} \mathrm{C}$ to provide the ashing process within a special heating cycle. Substrate components were carefully mixed together to obtain uniform mixture before filling in the bioreactors. Bioreactors were placed into a single heated thermostat for providing of constant temperature $38 \pm 0.5^{\circ} \mathrm{C}$ during the anaerobic digestion (AD) process. Gases were collected during anaerobic digestion in bag samples positioned outside the thermostat, and the volume of gases was measured regularly using the gas flow meter (drum-type, brand Ritter). The composition of gases in the gas sample was measured using the gas analyser (type GA 2000). pH value of substrates before starting and after finishing was clarified using the $\mathrm{pH}$ meter (PP-50).

Fermented cattle manure was utilized as the inoculum, and has very low organic matter content providing low biogas volumes released from inoculums, resulting in small biogas and methane volumes to be subtracted in calculations of true biogas and methane volumes from added biomass. The $\mathrm{AD}$ process was provided until biogas release was finished. Experimental data were processed using appropriate statistical methods. 


\section{Results and discussion}

The results of the investigation of sample substrates, including inoculums, lucerne pellets and birch leaves pellets with and without enzymes, before starting of the AD process are shown in Table 1 .

Table 1

Results of analyses of raw material samples before anaerobic digestion

\begin{tabular}{|l|l|c|c|c|c|c|c|c|}
\hline Bio-reactors & \multicolumn{1}{|c|}{ Raw material } & $\mathbf{p H}$ & $\begin{array}{c}\text { TS, } \\
\mathbf{\%}\end{array}$ & $\begin{array}{c}\text { TS, } \\
\mathbf{g}\end{array}$ & $\begin{array}{c}\text { ASH, } \\
\mathbf{\%}\end{array}$ & $\begin{array}{c}\text { DOM, } \\
\mathbf{\%}\end{array}$ & $\begin{array}{c}\text { DOM, } \\
\mathbf{\%}\end{array}$ & $\begin{array}{c}\text { Weight, } \\
\mathbf{g}\end{array}$ \\
\hline R1; R16 & IN & 7.61 & 4.72 & 23.6 & 23.7 & 76.30 & 18.007 & 500 \\
\hline R2-R4 & LP & & 89.68 & 8.968 & 20.06 & 79.94 & 7.169 & 10 \\
\hline R2-R4 & IN + 10LP & 7.65 & 6.39 & 32.568 & 22.7 & 77.3 & 25.176 & 510 \\
\hline R5- R8 & IN + 10LP + 0.5ml AA & 7.65 & 6.38 & 32.573 & 22.71 & 77.29 & 25.177 & 510.5 \\
\hline R9-R11 & 10BP & & 71.97 & 7.197 & 12.31 & 87.69 & 6.311 & 10 \\
\hline R9-R11 & IN + 10BP & 7.65 & 6.04 & 30.797 & 21.04 & 78.96 & 24.318 & 510 \\
\hline R12- R15 & IN + 10BP + 0.5mlAA & 7.65 & 6.03 & 30.802 & 21.05 & 78.95 & 24.319 & 510.5 \\
\hline
\end{tabular}

Note: IN - inoculums, $500 g$; LP - lucerne pellets; $B P$ - birch leaves pellets; $A A$ - alpha amylase; ASH - ashes; TS - total solids; DOM - dry organic matter (content in substrate before AD process); R1-R16 - bioreactors.

Lucerne pellets and birch pellets have a relatively high dry matter and organic dry matter content. They rapidly absorb moisture from the bioreactor, dissolve, but do not swim. The bacteria from inoculum can easily access the organic matter. The biogas and methane yield and methane percentage in biogas from the bioreactors R1 and R16, from the bioreactors R2 and R15 with added lucerne pellets or birch leaves pellets with or without enzyme additives are shown in Table 2. The biogas or methane yield from each bioreactor R2-R15was calculated by subtraction of respective average biogas or methane volume obtained from the control R1 and R16 bioreactors, Table 2.

Table 2

Production of biogas and methane

\begin{tabular}{|c|c|c|c|c|c|c|}
\hline Bioreactor & Raw material & $\begin{array}{c}\text { Biogas, } \\
\text { I }\end{array}$ & $\begin{array}{l}\text { Biogas, } \\
\text { l. } \text { g }^{-1} \text { DOM }\end{array}$ & \begin{tabular}{|c|} 
Methane \\
$\%$
\end{tabular} & \begin{tabular}{|c|} 
Methane, \\
I
\end{tabular} & $\begin{array}{l}\text { Methane } \\
1 \cdot g^{-1} \text { DOM }\end{array}$ \\
\hline $\mathrm{R} 1$ & IN & 0.2 & 0.011 & 1.30 & 0.003 & 0.0002 \\
\hline R16 & IN & 0.6 & 0.033 & 3.80 & 0.023 & 0.001 \\
\hline $\begin{array}{l}\text { Aver. R1, } \\
\text { R16 }\end{array}$ & IN & 0.4 & 0.022 & 2.55 & 0.013 & 0.0007 \\
\hline $\mathrm{R} 2$ & $\mathrm{IN}+10 \mathrm{LP}$ & 6.1 & 0.851 & 53.07 & 3.237 & 0.452 \\
\hline $\mathrm{R} 3$ & $\mathrm{IN}+10 \mathrm{LP}$ & 5.4 & 0.753 & 59.78 & 3.228 & 0.450 \\
\hline $\mathrm{R} 4$ & $\mathrm{IN}+10 \mathrm{LP}$ & 5.5 & 0.767 & 39.24 & 2.158 & 0.301 \\
\hline $\begin{array}{c}\text { Aver. R2-R4 } \\
\pm \text { st.dev. }\end{array}$ & IN + 10LP & $\begin{array}{c}5.67 \\
\pm 0.38\end{array}$ & $\begin{array}{c}0.790 \\
\pm \mathbf{0 . 0 5 3}\end{array}$ & $\begin{array}{c}50.70 \\
\pm 10.47\end{array}$ & $\begin{array}{c}2.874 \\
\pm 0.620\end{array}$ & $\begin{array}{c}0.401 \\
\pm 0.087\end{array}$ \\
\hline R5 & $\mathrm{IN}+10 \mathrm{LP}+0.5 \mathrm{ml} \mathrm{AA}$ & 6.2 & 0.864 & 51.42 & 3.188 & 0.445 \\
\hline R6 & $\mathrm{IN}+10 \mathrm{LP}+0.5 \mathrm{ml} \mathrm{AA}$ & 7.2 & 1.004 & 49.28 & 3.548 & 0.495 \\
\hline R7 & $\mathrm{IN}+10 \mathrm{LP}+0.5 \mathrm{ml} \mathrm{AA}$ & 6.7 & 0.935 & 53.38 & 3.583 & 0.5 \\
\hline $\mathrm{R} 8$ & $\mathrm{IN}+10 \mathrm{LP}+0.5 \mathrm{ml} \mathrm{AA}$ & 6.7 & 0.935 & 51.73 & 3.446 & 0.483 \\
\hline $\begin{array}{c}\text { Aver.R5-R8 } \\
\pm \text { st.dev. }\end{array}$ & $\mathrm{IN}+10 \mathrm{LP}+0.5 \mathrm{ml} \mathrm{AA}$ & $\begin{array}{c}6.70 \\
\pm 0.41\end{array}$ & $\begin{array}{r}0.935 \\
\pm \mathbf{0 . 0 5 7}\end{array}$ & $\begin{array}{r}51.43 \\
\pm 1.68 \\
\end{array}$ & $\begin{array}{c}3.446 \\
\pm 0.179 \\
\end{array}$ & $\begin{array}{c}0.481 \\
\pm 0.025\end{array}$ \\
\hline R9 & $\mathrm{IN}+10 \mathrm{gBP}$ & 3.8 & 0.602 & 41.11 & 1.562 & 0.248 \\
\hline $\mathrm{R} 10$ & $\mathrm{IN}+10 \mathrm{gBP}$ & 3.9 & 0.617 & 39.56 & 1.543 & 0.244 \\
\hline $\mathrm{R} 11$ & $\mathrm{IN}+10 \mathrm{gBP}$ & 3.0 & 0.475 & 31.80 & 0.954 & 0.151 \\
\hline $\begin{array}{c}\text { Aver. R9-R11 } \\
\pm \text { st.dev. }\end{array}$ & $\mathrm{IN}+10 \mathrm{~g} \mathrm{BP}$ & $\begin{array}{c}3.57 \\
\pm \mathbf{0 . 4 9} \\
\end{array}$ & $\begin{array}{c}0.565 \\
\pm 0.078 \\
\end{array}$ & $\begin{array}{r}37.93 \\
\pm 4.99 \\
\end{array}$ & $\begin{array}{c}1.353 \\
\pm 0.346 \\
\end{array}$ & $\begin{array}{c}0.214 \\
\pm 0.055 \\
\end{array}$ \\
\hline
\end{tabular}


Table 2 (continued)

\begin{tabular}{|c|c|c|c|c|c|c|}
\hline Bioreactor & Raw material & $\begin{array}{c}\text { Biogas, } \\
\quad 1\end{array}$ & $\begin{array}{l}\text { Biogas, } \\
\mathrm{l} \cdot \mathrm{g}^{-1} \text { DOM } \\
\end{array}$ & $\begin{array}{c}\text { Methane } \\
\%\end{array}$ & $\begin{array}{c}\text { Methane, } \\
\text { l }\end{array}$ & $\begin{array}{c}\text { Methane } \\
l \cdot g^{-1} \\
\text { DOM }\end{array}$ \\
\hline R12 & $\mathrm{IN}+10 \mathrm{~g} \mathrm{BP}+\mathrm{AA}$ & 3.9 & 0.617 & 39.72 & 1.549 & 0.245 \\
\hline R13 & $\mathrm{IN}+10 \mathrm{~g} \mathrm{BP}+\mathrm{AA}$ & 4.0 & 0.633 & 45.32 & 1.813 & 0.287 \\
\hline R14 & $\mathrm{IN}+10 \mathrm{~g} \mathrm{BP}+\mathrm{AA}$ & 4.0 & 0.633 & 42.2 & 1.688 & 0.267 \\
\hline R15 & $\mathrm{IN}+10 \mathrm{~g} \mathrm{BP}+\mathrm{AA}$ & 3.9 & 0.617 & 40.95 & 1.597 & 0.253 \\
\hline $\begin{array}{l}\text { Aver. R12-R15 } \\
\pm \text { st.dev. }\end{array}$ & $\mathrm{IN}+10 \mathrm{~g} \mathrm{BP}+\mathrm{AA}$ & $\begin{array}{c}3.95 \\
\pm 0.06\end{array}$ & $\begin{array}{c}0.625 \\
\pm 0.009\end{array}$ & $\begin{array}{r}42.08 \\
\pm 2.41\end{array}$ & $\begin{array}{c}1.662 \\
\pm 0.116\end{array}$ & $\begin{array}{c}0.263 \\
\pm 0.018\end{array}$ \\
\hline
\end{tabular}

Note: L $_{D_{D O M}}{ }^{-1}$ - litres per $1 \mathrm{~g}$ dry organic matter added (added fresh biomass into inoculums).

The results show that lucerne pellets are a very good raw material for methane production. Addition of enzyme Alpha amylase increased the methane yields significantly. There was much less methane from the birch pellets. Also, the addition of the enzyme alpha-amylase increased the yield of methane. The specific biogas and methane yields from bioreactors are shown in Figure 1.

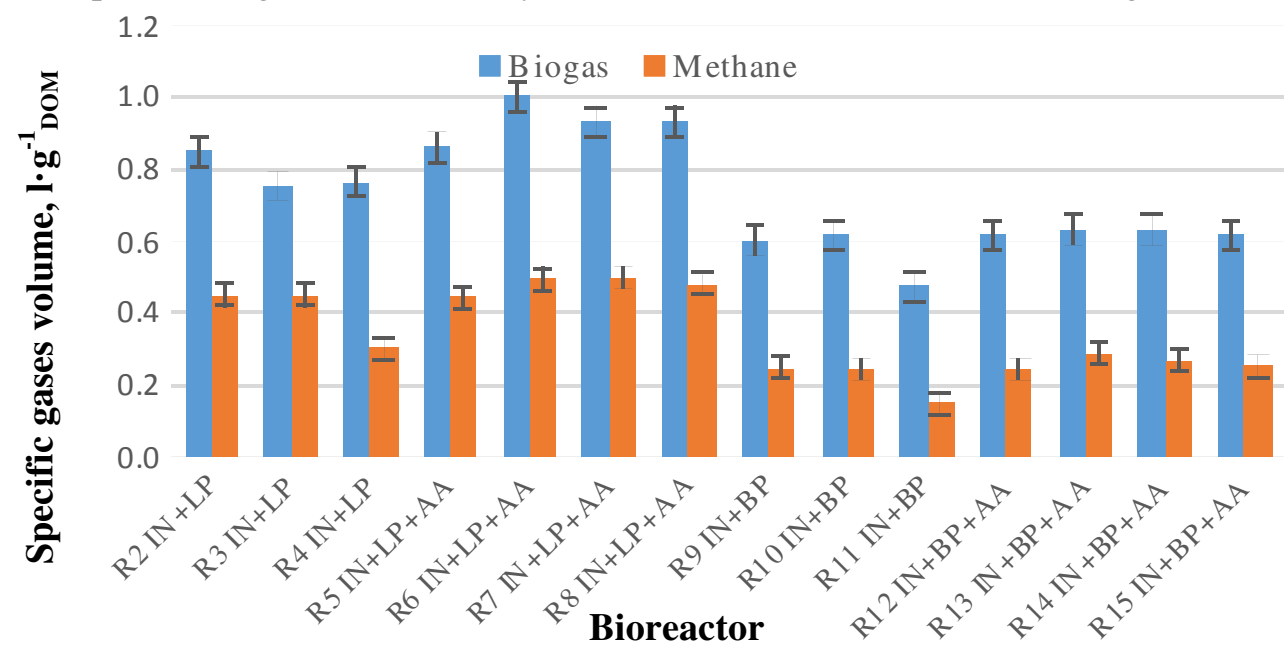

Fig. 1. Specific biogas and methane yields: $I N$ - inoculums; LP - lucerne pellets; $B P$ - birch leaves pellets; AA - Alpha amylase

The average methane contents in biogas from lucerne pellets, birch leaves pellets with and without enzymes are shown in Figure 2.

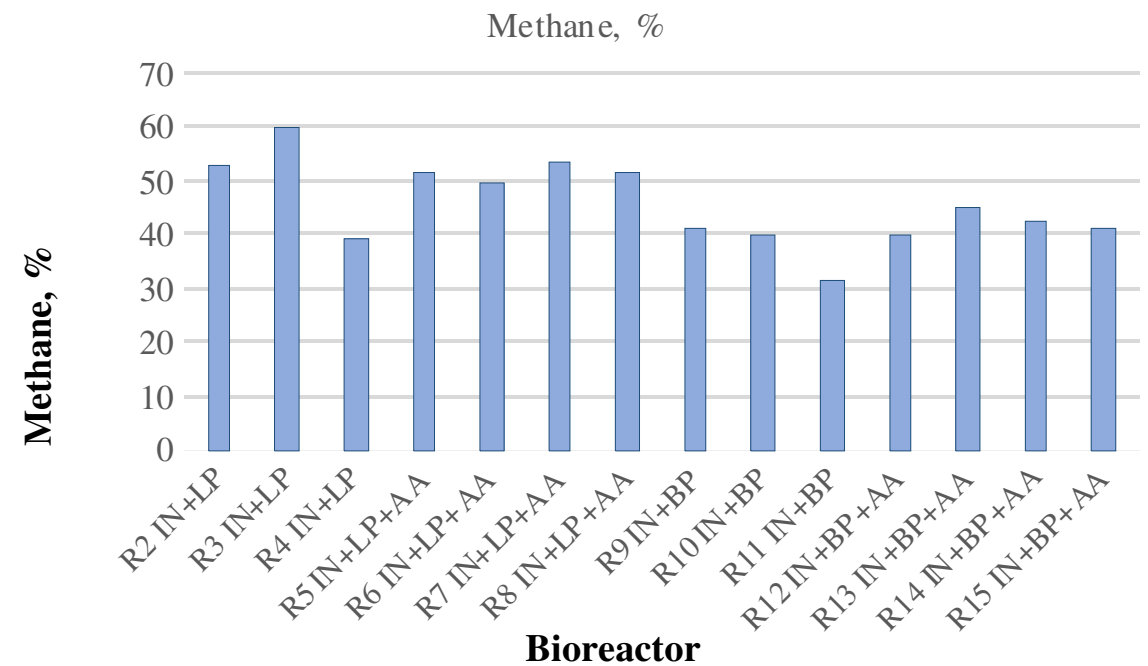

Fig. 2. Average methane contents in biogas from lucerne pellets, birch leaves pellets with and without enzymes: IN - inoculums; LP - lucerne pellets; BP - birch leaves pellets; AA - Alpha amylase 
The average methane content in biogas from lucerne pellets was $50.7 \%$ and it was $37.9 \%$ from birch leaves pellets and, if Alpha amylase was added, the average methane content increased to $51.43 \%$ or $42.8 \%$ in biogas from Lucerne pellets or birch pellets respectively. Addition of Alpha amylase increased the average methane content in biogas from lucerne pellets by $0.7 \%$ and by $4.2 \%$ from birch leaves pellets.

\section{Conclusions}

1. The yield of methane from lucerne pellets is $401 \mathrm{l} \cdot \mathrm{g}^{-1}$ DOM, which is a very good result.

2. Addition of enzyme Sinlucerne in pellets substrate resulted in a $19.95 \%$ increase in the methane yield.

3. Addition of enzyme Alpha amylase in birch leaves pellets substrate resulted in a $22.9 \%$ increase in the methane yield.

4. Birch leaves pellets and lucerne pellets, especially if the enzyme Alpha amylase is added, can be successfully used as raw materials for methane production.

5. Addition of Alpha amylase increases the average methane content in biogas from lucerne pellets or birch leaves pellets by $0.7 \%$ or $4.2 \%$ respectively.

6. Birch leaves pellets un lucerne pellets can be successfully used for partly replacing of maize silage.

\section{References}

[1] Divya D., Gopinath L.R., Christy P. Merlin. A review on current aspects and diverse prospects for enhancing biogas production in sustainable means.Renewable and Sustainable Energy Reviews, Volume 42, 2015, pp. 690-699.

[2] Bruni E., Jensen A. P., Angelidaki I. Comparative study of mechanical, hydrothermal, chemical and enzymatic treatments of digested biofibers to improve biogas production. Bioresource Technology, 101(22), 2010, pp. 8713-8717.

[3] Oszust K., Pawlik A., Janusz G., Ziemiński K., Cyran M., Siczek A., Gryta A., BilińskaWielgus N., Frąc M. Characterization and influence of a multi-enzymatic biopreparation for biogas yield enhancement.BioRes.,12(3), 2017, pp. 6187- 6206.

[4] Parawira W. Enzyme research and applications in biotechnological intensification of biogasp roduction. Crit Rev Biotechnol., 32(2), 2012, pp. 172-186.

[5] Prasad S.P., Meher K.K. Anaerobic digestion of Solid Waste: A Focus on Microbial Community Structures; in book "Recycling of Solid Waste for Biofuels and Bio-chemicals". Springer, 2016, pp. 127-163.

[6] Angelidaki I., Alves M., Bolzonella D., Borzacconi L., Campos J., Guwy A., Kalyuzhnyi S., Jenicek P., Van Lier J. Defining the biomethane potential (BMP) of solid organic wastes and energy crops: a proposed protocol for batch assays. Water Sci Technol., 59(5), 2009; pp. 927-934.

[7] Jianchang L., Kewei S., Juan H., Qiuling C. Using an Amylase Pretreatment of Pig Manure to Enhance Biogas Production. Proceedings of Asia-Pacific Power and Energy Engineering Conference, 2011, pp. 2783-2788.

[8] Quiñones T.S., Plöchl M., Päzolt K., Budde J., Kausmann R., Nettmann E., Heiermann M. Hydrolytic Enzymes Enhancing Anaerobic Digestion. in: Biogas Production, John Wiley \& Sons, Inc., 2012, pp. 157-198.

[9] Bochmann G., Herfellner T., Susanto F., Kreuter F., Pesta G. Application of enzymes in anaerobic digestion. Water Science and Technology, 56, 10, 2007, pp. 29-35.

[10] Dubrovskis V., Plume I. Enzymatic and catalystic enchancement of methane production from corn silage and grain residues. Proceedings of 16. Conference Engineering for Rural Development, Vol. 16 2017, pp. 443-448.

[11] Kumar K.V., Sridevi V., Rani1 K.M., Sakunthala M., Kumar C.S. A review on production of biogas, fundamentals, applications \& its recent enhancing techniques, Elixir Chem. Engg., 57, 2013, pp. 14073-14079.

[12] Rintala J.A., Ahring B.K. Thermophilic anaerobic digestion of source-sorted household solid waste: the effects of enzyme additions. Applied Microbiology and Biotechnology, 40, 1994, pp. 916-919. 
[13] Thran D. Methodenhandbuch Energetische Biomassenutzung, (Methods Manual Energetic use of biomass). 2010, Leipzig, 93 p. (In German).

[14] VDI 4630 Vergärungorganischer Stoffe Substratcharakterisierung, Probenahme, Stoffdatenerhebung, Gärversuche. Vereindeutscher Ingenieure (Fermentation of organic substances, Substrate characterization,sampling, substance data collection, fermentation tests. German engineers), Düsseldorf, 2006, 48 pp. (In German). 